\title{
REGULATION, REREGULATION, AND DEREGULATION: THE POLITICAL FOUNDATIONS OF AGENCY CLIENTELE RELATIONSHIPS*†
}

\author{
Barry R. Weingast $\ddagger$
}

I. A Model of Regulatory Policy Equilibrium 149

A. Congress, Interest Groups, and Regulatory Agencies ...................... 150

1. Congressional Structure and Policy-making …............................ 150

2. Congressional Control of Agencies ............................................ 151

3. Conclusion …............................................................................ 153

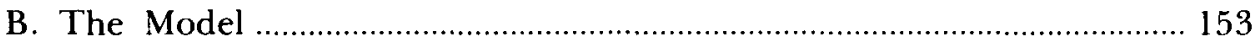

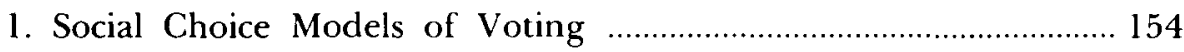

2. Assumptions of the Model ........................................................ 155

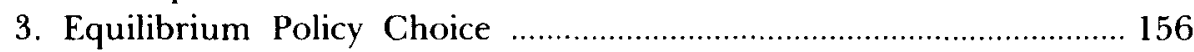

C. Implications for Regulatory Behavior ......................................... 158

II. Equilibrium Change: The Comparative Statics of Regulatory Policy ....... 161

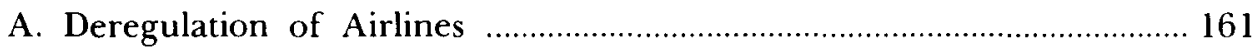

1. Changes in Public Opinion and Active Constituents .................. 161

2. Presidents and other Political Entrepreneurs .............................. 162

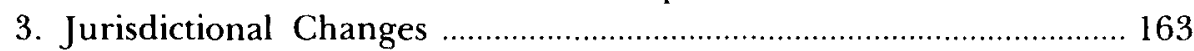

4. Political Transformation of Airline Regulation, 1970-1978 ....... 165

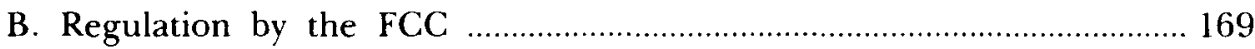

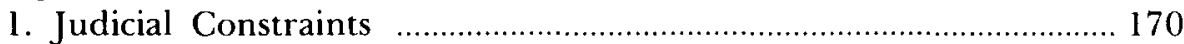

2. Television Regulation ................................................................ 170

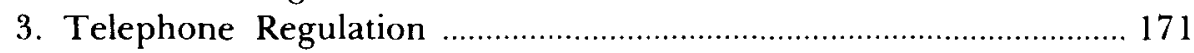

C. Nuclear Power Regulation \& the Environmentalists ......................... 172

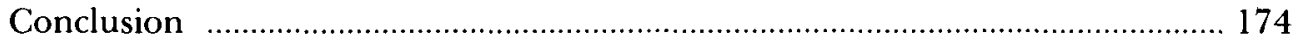

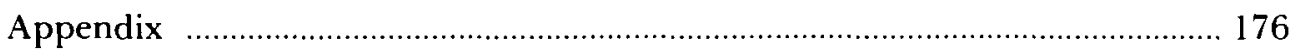

* O Copyright 1981 by Duke University.

† I am grateful to Randy Calvert, Linda Cohen, Mo Fiorina, George Hay, Paul Joskow, and Ken Shepsle for helpful comments and to Mark Moran for his valuable research assistance.

$\ddagger$ Assistant Professor of Economics and Research Associate, Center for Study of American Business, Washington University. 
As we move into the 1980s, two seemingly incongruous trends in regulation are apparent. First, the remarkable growth in regulation, particularly in the social and environmental areas, has led to unprecedented levels of federal intervention in the economy. Second, and as yet less significant in its total impact, there exists a counter-trend of deregulation, particularly in many areas of direct economic regulation. Analysis of these trends falls within the political field and outside the traditional expertise of economists studying regulation. Nonetheless, natural questions arise: How are these trends to be accounted for? While we have reasonably good models predicting the behavior of firms given different regulatory constraints and changing regulations, we have little systematic analysis that allows similar understanding of political events of direct relevance to the concerns in the literature. ${ }^{1}$ For example, why have certain regulatory arenas been relatively stable over the past few decades only to go through major changes in recent years? Why did deregulation of the Civil Aeronautics Board (CAB) occur in 1978 and not 1968? Why has one side of the Federal Communications Commission (FCC) (common carrier regulation) promoted competition with regulated industries for over a decade while the other side (over-the-air broadcasting) hindered competition for nearly twenty years? More generally, where is deregulation most likely to occur or likely to be successful? Finally, what is the role of economic analysis in these events?

These are some of the issues relevant to economic analysis of regulation, yet economists have no framework to address these concerns. Both popular and scholarly discussions of regulatory policy-making focus on the agency as the source of political decisions without a broader view of the role of the agency within the political system. Popular characterizations of agency policy usually consider agency decisions in terms of a "runaway bureaucracy" working for its own interests rather than those of the public. Similarly, in the scholarly literature, both economists and political scientists studying regulatory policy-making typically employ research strategies that focus on an agency. For example, "What are the economic effects of regulation by the $\mathrm{CAB}$ or the Food and Drug Administration (FDA)?"2

1. Many scholars have contributed to this area by raising the appropriate concerns and attempting to explain them. Nonetheless, no body of theory exists that may be used to address these concerns. See generally, L. Davis \& D. North, Institutional Change and American Economic Growth (1971); R. Noll, Reforming Regulation (1971) [hereinafter cited as Reforming Regulation]; B. Owen \& R. Braeutigam, The Regulation Game: Strategic Use of the Administrative Process [hereinafter cited as OWen \& Braeutigam]; Joskow, Inflation and Environmental Concern: Structural Change in the Process of Public Utility Price Regulation, 17 J. L. \& Econ. 291, 294-327 (1974); Peltzman, Toward a General Theory of Regulation, $19 \mathrm{~J}$. L.\& ECoN. 211 (1976) [hereinafter cited as Peltzman]; Stigler, The Theory of Economic Regulation, 2 BELL J. ECON. 3 (1971); P. Aranson, The Uncertain Search for Regulatory Reform, 1979 (Working Paper No. 79, Law and Economics Center, University of Miami); and R. Noll, What is Regulation?, 1979 (Mimeo from California Institute of Technology) [hereinafter cited as What is Regulation?]. Relevant works from political science literature include: M. Bernstein, Regulating Business by Independent Commission (1955); T. Lowi, The End of Liberalism (2nd ed. 1979) [hereinafter cited as Lowi]; and J. Wilson, The Politics of Regulation (1980) [hereinafter cited as WILSON].

2. See What is Regulation?, supra note 1, regarding the narrow focus of most studies of regulatory policy. 
Peltzman, in his search for an understanding of why regulation might benefit organized industry groups instead of consumers, moves away from a simple agency focus to a broader look at the political system. ${ }^{3}$ His approach incorporates a votemaximizing politician called the "regulator." The model rests on a contrast between producers and consumers. Peltzman argues that because more concentrated producers have both lower organization costs and higher individual stakes in regulatory policy, they provide greater political support to the regulator. Hence policy benefits flow disproportionately (though not exclusively) to the producers at the expense of the consumers. This important contribution helps explain one set of regulatory circumstances.

The limitations with Peltzman's analysis in dealing with the issues raised above are threefold: First, the model seems more applicable to the industry-specific regulation $(\mathrm{CAB}, \mathrm{ICC}, \mathrm{FCC})$ and the influence of concentrated interest groups and less suited to industry-wide regulation (OSHA, CPSC, EPA) and the influence of more diffuse groups such as labor, consumerists or the environmentalists. Second, the model is incomplete even for industry-specific agencies: deregulation has significantly altered these agencies in a manner not explained by the model. Third, the simple political actor has no real world counterpart in our political system.

Our inability to understand the major transformations of various regulatory arenas over the last decade provides the motivation for this article. The model developed below presents an equilibrium theory of regulatory policy-making that focuses on the conditions that foster stability on the one hand, and those that stimulate change on the other. Part I develops the first task in three stages. First, it presents a general discussion of the relationships between agencies, interest groups, and politicans; second, the model presented reveals the logic underpinning an equilibrium policy choice; and finally, the implications of this abstract model are developed for agency policy-making. Part II extends the model to explore the factors involved in policy change. This is done by using the model to predict the effect of certain changes in independent variables and then applying these predictions to three case studies: deregulation of the CAB, a contrast between the FCC's fostering of competition in telephone regulation and protection of the status quo for broadcast regulation; and third, the nature of the influence of the environmentalists in nuclear power.

\section{A Model of Regulatory Policy Equilibrium}

A wide variety of political actors with diverse goals interact to make policy. These include Congress (especially members of the key committees), the president, the courts, interest groups, and of course, the agencies themselves. Each plays a specialized role; understanding final policy outcomes requires understanding the influence of each political actor. The main argument of this Section can be summarized succinctly. Agency policy equilibrium results from combinations of

3. Peltzman, supra note 1. 
three factors: low or intermittent presidential interest; clear court precedents with little expectation of change; and stable patterns in public opinion and the relative balance of interest groups.

For most agencies, the influence of the president is sporadic or unimportant; and while courts are an ever-present constraint in the form of procedure, most agencies do not experience interventionist judicial behavior or regularly changing precedents. To the degree that agency policy remains stable, therefore, it reflects an equilibrium derived from the behavior and strategic choices of Congress, interest groups and agencies.

\section{A. Congress, Interest Groups, and Regulatory Agencies}

In order to model outcomes of the interaction among these players, we need first to examine the political institutions that provide them with opportunities for cooperation and mutual exploitation.

\section{Congressional Structure and Policy-making}

Committees and subcommittees dominate the policy-making process. These institutions limit the political choice possibilities, and thus play a crucial role in determining the political allocation of resources. ${ }^{4}$ Two features of these institutions mold policy choice. First, the committee system divides the legislative responsibilities into separate policy jurisdictions. Within its policy area, a committee and its members wield a disproportionate influence over policy. This includes a number of special powers such as control over proposals for new legislation and for agency policy oversight. Second, committee membership is primarily a self-selection mechanism. ${ }^{5}$ Congressmen typically gain influence over policy of direct interest to their district. Because of their differential influence over policy in a given area, these members exploit their greater influence over the fate of relevant interest groups in return for electoral support.

This division of policy areas provides the foundation for the policy-making process. The fragmentation of policy issues into separate jurisdictions lumps a small number of interest groups, congressmen, and agencies together. These three sets of actors have divergent but compatible goals. Interest groups seek the benefits of legislation and policy-making. ${ }^{6}$ For example, firms seek benefits in a variety of

4. This Section draws on the major works in political science on Congress and policy-making, particularly those relying on the rational choice approach. Notable research includes: R. FENNO, CONGRESSMEN in Committees (1973) [hereinafter cited as Congressmen in Committees]; R. Fenno, Home Style (1978); M. Fiorina, Congress: Keystone of the Washington Establishment (1977); M. Fiorina, Representatives, Roll Calls, and Constituencies (1974) [hereinafter cited as Representatives, Roll Calls, and Constituencies]; Lowi, supra note 1; and Mayhew, Congress: The Electoral Connection (1974) [hereinafter cited as MAYHEW].

5. Freshman legislators are appointed to one of their first three choices (out of twenty-two) over 80 percent of the time. Returning congressmen seeking to switch committees do even better. Finally, when combined with those congressmen who remain on the same committee, the average frequency of landing on the first, second, or third choice approaches one. See K. Shepsle, The Giant Jigsaw Puzzle (1978).

6. Interest groups include a wide range of collective behavior. Following Fiorina, "We use the term 'group' as a kind of shorthand for the opinion sectors into which the representative divides the district; no false personification is implied. A group may be a well-defined formal entity, such as COPE or the Possum 
forms, ranging from minor improvements in their rights under the status quo to full cartelization. Similarly, single issue groups such as the civil rights advocates, the environmentalists, war veterans, or the National Rifle Association (NRA) seek to further their own interests and policy goals. Agencies are simply one vehicle for this purpose.

Congressmen seek reelection and career advancement. This implies that they bend with the wind of public opinion in general, and further the interests of attentive and politically active interest groups in particular. Often, this entails that a particular congressman becomes identified with a specific policy area. While Congress as a whole may have little interest in an agency, this congressman, by virtue of his committee power may wield an enormous influence. Examples of prominent congressmen associated with a particular area come to mind readily: Senator Cannon on aviation and transportation policy; Senator Pastore on broadcast regulation; Congressman Price on atomic energy; Senator Kennedy on health; Senator Long (and until recently, Congressman Mills) on tax policy; and finally, Senator Muskie (until recently) on environmental policy. These congressmen, from their key committee positions, pursue their electoral goals and policy initiatives through exploitation of the relevant interest groups and of public opinion. The greater the potential rewards, the more ripe it is for new policy initiatives.

Often, agencies are the vehicle for this endeavor. Agency heads and commission members, anxious to further their careers and goals of power and prestige (including large budgets) as well as completing their own pet projects and policy initiatives, depend upon service to interest groups and key committee members for their success.

In a real sense, the goals of these three sets of players are compatible. Congressmen, seeking reelection and national prominence, further the interests of new and established groups. Agencies aid powerful politicians-generally congressmen on relevant committees, though presidents are important at times — by implementing policies beneficial to constituent groups relevant for a particular policy area. Finally, the interest groups reward politicians through aiding reelection. This advances Congressional careers and helps the potential success of policy initiatives, a key to national prominence.

\section{Congressional Control of Agencies}

The relationship between a committee and an agency within its policy jurisdiction is widely misunderstood. Most observers take the absence of regular congressional hearings, investigations, and legislation to signal a lack of interest or control. ${ }^{7}$

Hollow Rod and Gun Club, a demographic segment of the constituency such as Catholics or Blacks, or an 'issue public' such as pro-prayer in schools." Representatives, Roll. Calls, and Constituencies, supra note 4 , at 31 .

7. For example, see L. Dodd \& R. Schott, Congress and the Administrative State (1979); and K. Clarkson \& T. Muris, The Federal Trade Commission and Occupational Regulation, 1979 (Working Paper No. 79-5, Law and Economics Center, University of Miami). For a fuller development of the thesis presented in this paper, see R. Calvert and B. Weingast, Six Myths of Regulation: Congress, the Bureacracy, and Regulatory Reform, 1980 (mimeo from Center for the Study of American Business, Washington University). 
However, committees fail to undertake these easily observed and resource intensive techniques of official oversight because more subtle and less expensive techniques serve the same function.

Congressional influence over agency decisions does not proceed by considered, public deliberations that result in a clear resolution of policy issues. Rather, agency control and "oversight" tends to occur through the informal, indirect and ex parte. This includes a variety of techniques from the budgetary process. Earmarking of funds, forbidding expenditures for particular purposes or programs, as well as control over size of budget, personnel, and other prestige items such as personal perquisites are all used regularly. As Wildavsky argues, the agencies most successful in this process are those that serve congressional clienteles. ${ }^{8}$ Additionally, other more subtle techniques are available. For example, a source of influence of great potential but generally of low visibility is the appointment process. Regulatory commissioners owe their appointments (and reappointment possibilities) to Congress. The evidence suggests that except during unusual times in which the president includes this policy area in his personal political program, this influence is left to Congress. As with the budgetary process, this power is exercised on behalf of congressional constituents. ${ }^{9}$

Finally, hearings and investigations are used to influence decisions and stymie unwanted policy initiatives by uncooperative agency members (with potentially negative consequences for careers). The incentives provided by the threat of large-scale intervention may be the most important consequence of sporadic, but carefully targeted, congressional investigations. Consequently, agencies undertake few policy initiatives without informal congressional consent. ${ }^{10}$

8. Wildavsky stresses that an agency must cultivate a clientele. In particular, to be successful, he advises agencies to "serve your clientele," "expand your clientele," "secure congressional and clientele feedback," and "concentrate on individual constituencies" (i.e., be specific about which groups benefit from particular programs or potential changes in policy). A. Wildavsky, The Politics of the Budgetary Process 65-69 (1974).

9. Referring to industry-specific regulation, Noll argues "In theory, regulatory commissions are composed of neutral, objective experts on the affairs of the regulated industry, and on the public interest in the behavior of the regulated. In practice, appointees to commissions must have the tacit approval of the regulated industries. Appointments, almost unnoticed by the general public, are closely watched by regulated firms. Rarely does the President appoint and the Senate confirm a commissioner if the regulated industry is politically aligned against him. While the appointments process does not necessarily produce commissioners who are consciously controlled by the industry they regulate, it nearly always succeeds in excluding persons who are regarded as opposed to the interest of the regulated." REFORMING Regulation, supra note 1 , at 43 . While Noll's discussion focuses on industry-specific regulatory agencies and regulated firms, one could substitute "congressional constituency" in this passage and have an apt characterization of nearly all regulatory agencies. Moreover, a recent study undertaken by the Senate Commerce Committee confirms this conclusion. "In an investigation of all appointments to the FCC and the FTC during the twenty-five year period, 1949-74, Congress played a major role in the appointment of particular members; in nearly half, congressional sponsorship was the sole motivation for the appointment." See Committee on Commerce, 94th Cong., 2d Sess., Appointments to the Regulatory Agencies (Comm. Print 1976).

10. As Noll observes, ". . . in no meaningful sense is regulation independent, especially of Congress." Moreover, " [a]lthough the president could exercise authority over regulatory agencies, there is little evidence that he or his administration makes much of an attempt to do so." REFORMING; REGULATION, supra note 1 , at 34, 36. For other studies on congressional-agency relations drawing similar conclusions, see $W$. Cary, Politics and the Regulatory Agencies (1967); L. Kohlieier, The Regulators (1969) [hereinafter cited as Kohlmeier]; E. Krasnow and L. Longley, The Politics of Broadcast Regulation (2nd ed. 1978) [hereinafter cited as KRASNOW AND LONGLEY]. 
Notice the implications of these incentives in perfect operation. First, if agencies follow their cues and congressional guidance, we would observe little ostensible committee attention. No resources need be devoted to a policy area functioning properly; rather, hearings and legislation are invested in those areas not functioning smoothly. Second, the appropriate congressional clientele relationships are maintained-indeed, some agencies may appear captured by their clientele. And finally, congressmen may appear ignorant of policy and agency proceedings. This stems from the fact that congressmen judge the success of agency decisions based on constituency reaction, and not through detailed, systematic study and oversight.

\section{Conclusion}

Because the interests of the committee with policy jurisdiction, the agency, and the relevant interests groups are compatible, they form an integral and partially autonomous political unit for mutual gain. This tripartite set of actors will be labeled subgovernments in the following discussion, though various other terms are used in the political science and popular literatures, such as, "cozy legislative triangles," and "iron triangles." 11 As Part II shall demonstrate, subgovernments are not immutable, iron triangles. In fact, policy-making is subject to a variety of outside forces from which the three principal parties are only partially insulated.

Interest groups wield influence over a particular area because the committee and subcommittee structure of Congress roughly parallels the important groups. By partially isolating the politically important groups into different political arenas, this structure allows each set of interests to have disproportionate influence in one area.

\section{B. The Model}

The subgovernment structure of policy-making, repeated across diverse areas, implies that congressmen are typically very powerful within their policy domain, but have little influence outside this area. The preceding discussion provided the foundation for the following assumptions. First, public opinion and the active interest groups determine the preferences of congressmen, and second, congressmen control agencies. To understand policy decisions, therefore, we turn to an analysis of congressional institutions to understand the opportunities available to committee members to serve their clientele. This Section provides an analytical model of the operation of subgovernments using modern social choice theory. This allows the notion of the "increased influence" of key committee members to be modeled more precisely.

11. The literature on policy subgovernments is quite extensive, though most contain descriptive analysis rather than theoretical development. See D. Cater, Power IN Washiviton (1964): J. Freemax, The Political Process: Executive Bureau-Lecislative Commttee Reintions (rev. ed 1965); R. Davidson, Breaking Up Those Cozy Triangles: An Impossible Dream?, Symposium on Legislative Reform and Public Policy (1976). Finally, the influence of Lowi will be found throughout this essay, particularly regarding the policy consequences. See Low's supra note 1. 


\section{Social Choice Models of Voting}

Modern social choice theory is an approach to modeling voting procedures. ${ }^{12}$ Typically, the focus has been on simple majority rule. A major question guiding this literature concerns the existence of equilibrium. For a set of policy alternatives, say $A, B, C, \ldots Z$, where a set of voters is to choose among these, a global equilibrium for majority rule is an alternative that commands a majority against all other alternatives. If a global equilibrium exists, then policy choice can be both predictable and stable. Any other policy alternative is unstable since the equilibrium is preferred to this alternative by a majority. Moreover, once the equilibrium is selected, no policy can replace it.

Social choice theorists have investigated the likelihood that such equilibria exist. The basic results show that, in general, no equilibrium exists for majority rule. ${ }^{13}$ Rather, for any particular policy alternative, there exists some other alternative that commands the support of a majority against it.

Cycles of the following type exist: alternative $\mathrm{A}$ beats $\mathrm{B}$; $\mathrm{B}$ beats $\mathrm{C}$; but $\mathrm{C}$ beats A. McKelvey has shown that these cycles are pervasive, extending over the entire policy space. ${ }^{14}$ This implies that as long as new proposals can be made, majority rule choice has no natural stopping point.

As social choice theorists point out, this extreme sort of instability in majority rule voting means that final policy selection depends upon seemingly arbitrary considerations such as the order in which the alternatives arise for comparison (hereinafter called the "agenda"). ${ }^{15}$ This conclusion can be stated in another more useful manner: for any set of voter preferences over policies, the existence of policy cycles implies that any point may be the final policy choice of the appropriately chosen agenda.

The agenda, therefore, plays a crucial role in policy choice. Those with the power to manipulate the agenda gain considerable influence over final policy choice. Moreover, to the degree that the rules of policy choice institutionalize agenda control in a well-defined manner, the influence of the agenda will be non-random and subject to analysis. Pursuing this line, social choice theorists have recently turned their attention from simple majority rule institutions to the study of more complex institutions with specific rules governing agenda control. ${ }^{16}$ One of the main themes of this research is the role played by institutions in the creation of

12. See Plott, Axiomatic Social Choice Theory, 20 Aм. J. Politicial Sc: 511 (1976).

13. See Cohen, Cyclic Sets in Multidimensional Voting Models, 20 J. EcoN. ThEoRY 1 (1979); McKelvey, General Conditions for Global Intransitivities in Formal Models of Voting, 47 Ecoxometric:A 108 (1975) [hereinafter cited as McKelvey]; Plott, A Notion of Equilibrium and its Possibility under Majority Rule, 57 Am. Econ. Rev. 787 (1967).

14. See McKelvey, supra note 13 .

15. On the strategic use of the agenda, see Plott \& Levine, A Model of Agenda Influence on Committee Decisions, 68 Aм. ECON. Rev. 146 (1978).

16. See Shepsle, The Role of Institutional Structure in the Creation of Policy Equilibrium, in Public PoLICY AND Public Choice (D. Rae \& T. Eismeier eds. 1979) [hereinafter cited as Role of Institutional Structure]; Kramer, Sophisticated Voting over Multidimensional Choice Spaces, 2 J. MATH Soc. 165 (1972) [hereinafter cited as Kramer]; Romer \& Rosenthal, Political Resource Allocation, Controlled Agendas, and the Status Quo, 33 Pub. Choice 27 (1978); and Shepsle, Institutional Arrangements and Equilibrium in Multidimensional Voting Models, 23 Aм. J. Political SCI. 27 (1979) [hereinafter cited as Institutional Arrangements and Equilibrium]. 
stable policy choice. Institutions may induce a determinant social choice by restricting the types of policy comparisons that can arise for a vote by the entire body.

\section{Assumptions of the Model}

An important feature of the congressional committee system is that it serves this function precisely. To see how this works, consider a representative legislature with $\mathrm{n}$ members. Each member is the elected representative of a given, geographicallybased district. Representatives are assumed to maximize the probability of reelection based on their influence over legislative policy decisions on behalf of their constituents.

Throughout the following, legislators are simply assumed to rationally calculate the likely effects of various actions (e.g., voting decisions, introduction of legislation, or agenda control) upon their reelection chances. That is, each legislator has an electorally-induced set of preferences over the policies. ${ }^{17}$ Three aspects of the induced preference relations should be noted. (1) Legislators pursue benefits primarily for their particular reelection constituency in their district. Since only the latter bear significantly on their electoral fortunes, representatives weigh these effects more heavily than those borne by other constituencies. (2) Because different geographic areas typically have different constituency interests, representatives' preferences differ systematically across districts. (3) Finally, changes in the political issues and the types of policies that generate votes change the induced preferences.

Representatives pursue their reelection goals within the confines of the leglislative rules which may be described as follows. The set of legislators is divided into subsets called committees. Each legislator is a member of a particular committee. Associated with each committee is a subset of the policies called its policy jurisdiction. Committees play key roles in legislative policy choice within their jurisdiction. The legislature delegates each committee two sets of powers. First, committees are granted agenda power within their jurisdiction; any change in the status quo, $x^{0}$, must be proposed by the committee. ${ }^{18}$ Agenda power also conveys veto power to the committee since any change in the status quo not desired by the committee will not be proposed by the committee. Second, the committee system delegates committees oversight authority to control and manage existing programs and agencies within their respective jurisdictions. Here, the strategic problem of the

17. The conclusions concerning the relationship of a representative's electorially induced preferences and his constituency interests are developed further in B. Weingast, Congress and Regulation: A Social Choice Theory of Political Intervention, 1980 (mimeo from Center for the Study of American Business, Washington University). See also Representatives, Roll Calls and Constituencies, supra note 4.

18. A notable absence from this formulation is the possibilities of amendments of committee proposals. It can be shown that with a completely open rule, that is, no restrictions on amendments that may be proposed, then the situation is precisely analogous to pure majority rule with no equilibrium. See Role of Institutional Structure, supra note 16. However, the so-called open rule employed in Congress involves a significant number of restrictions placing it somewhere between a completely open rule and the closed rule (no amendments). While it remains an open question as to how strong an assumption this is, the following observation suggests that it is reasonable: the frequency of passage of committee legislation is over 90 percent under the "open rule," see Dyson \& Soule, Congressional Committee Behavior on Roll Call Vote, 14 Midwest J. Pol. Sci. 626 (1970). 
committee members is to control agency policy subject to the constraints placed on agency choice in the original legislation. ${ }^{19}$

To summarize, the assumptions of the model are as follows. Representatives maximize the chances of their reelection based upon the effects upon their politically active constituencies (Al). For the enactment of new legislation, each committee gains agenda power within its jurisdiction; new proposals are subject to majority rule approval (A2). Committees have complete oversight control within their jurisdictions, subject to legislative and judicial constraints (A3). Finally, committee assignments are based upon self-selection (A4).

\section{Equilibrium Policy Choice}

Having described the assumptions of the model of the legislature, we now derive its implications. The main conclusion is that because the committee system lodges agenda control with a particular committee, stable choice may result even in the absence of global equilibrium. To see how this works, consider a particular committee together with its policy jurisdiction, $\mathrm{X}$. Throughout the following discussion, the committee will be considered as a unit. As in the case of a dominant committee (or subcommittee) chairman, a stable, decisive coalition of committee members is assumed to control committee choice. This allows the presumption of consistent, joint committee preferences over policy alternatives and avoids cycles within the committee. ${ }^{20}$

To begin the analysis, let $x^{0}\left(x^{0} \in X\right)$ be the status quo policy state in this policy jurisdiction. For any given policy, two sets are important in determining equilibrium. First, unless a particular alternative, $\mathrm{x}$, happens to be the ideal policy judged by the committee, there will be a set of points that the committee prefers to $x$. Let $\mathrm{S}(\mathrm{x})$ be this set. Second, since global equilibria do not exist in general, any policy alternative in the policy space has a corresponding set of points, $W(x)$, that commands a majority of voters against it. For the status quo, this means that $\mathrm{W}\left(\mathrm{x}^{0}\right)$ is the set of alternatives that beat $x^{0}$. To see that these sets differ, notice that $W(x)$ only requires that a majority of all legislators prefer points in $W(x)$ to $x$ and says nothing about the preferences of committee members. Similarly, $S(x)$ only requires that committee members prefer these points to $\mathrm{x}$ and requires nothing about the preferences of all other legislators; hence, these policies may or may not command a majority against $x$.

Since only policies in $W\left(x^{0}\right)$ beat $x^{0}$, the committee treats $W\left(x^{0}\right)$ as a constraint set in its effort to secure the best possible policy alternative. An equilibrium of this

19. A restriction imposed on nearly all agencies is the Administrative Procedures Act and the rule of administrative law that restricts the mechanics of agency operation. Many scholars note the opportunities provided here for strategic manipulation via the judicial process. See OwE.N \& BraEUtigam, supra note 1; What is Regulation?, supra note 1.

20. Technically, this assumes that the committee choice function is acyclic. This assumption is made for simplicity. As long as a committee chairman with agenda power exists, then, even though the committee is subject to the same condition of no global equilibrium choice, the agenda control may be used by the chairman to induce stable choice. Thus, the problem is really a two-stage recursive process of agenda control and voting choice (once in committee and once in the legislature). For convenience, one stage is omitted from analysis. 
legislative committee system is simply an alternative that the committee cannot improve upon. A structure-induced equilibrium is a policy $\mathrm{x}^{*}$ such that $\mathrm{W}\left(\mathrm{x}^{*}\right) \cap \mathrm{S}\left(\mathrm{x}^{*}\right)=\phi$. Or, in words, $x^{*}$ is a structure-induced equilibrium if none of the policies that command a majority against $x^{*}$ (i.e., $W\left(x^{*}\right)$ ) is preferred by the committee to $x^{*}$ (i.e., in $S\left(x^{*}\right)$ ). $x^{*}$ is simply the best the committee can do given the majority rule constraint set, $W\left(x^{*}\right)$. Alternatively, if for some policy, $x, S(x)$ and $W(x)$ overlap (i.e., $S(x) \cap W(x) \neq 0$ ], then there exist policy states preferred to $x$ by the committee that also gain majority approval against $x$. Hence $x$ cannot be an equilibrium.

It can be shown that structure-induced equilibria exist under the committee system with agenda control even if no global equilibrium exists. ${ }^{21}$ Given a status quo, $\mathbf{x}^{0}$, the lack of global equilibrium implies that $W\left(x^{0}\right)$ is nonempty. However, none of the alternatives that beat $x^{0}$ will be submitted for a vote by the legislature since this outcome assures that the committee will be worse off.

The consequences of this model and the nature of the structure-induced equilibrium policy choice may be developed using the five-person legislature depicted in Figure 1. Points on the graph represent policy alternatives in a two-dimensional policy space. The two policy variables are labeled "subsidy level to industry $x$," and "subsidy level to industry $y . "$ Legislators have differing preferences of subsidy levels for $x$ and $y$. Each legislator is assumed to have a most preferred policy, called an ideal point that represents the combination of subsidies

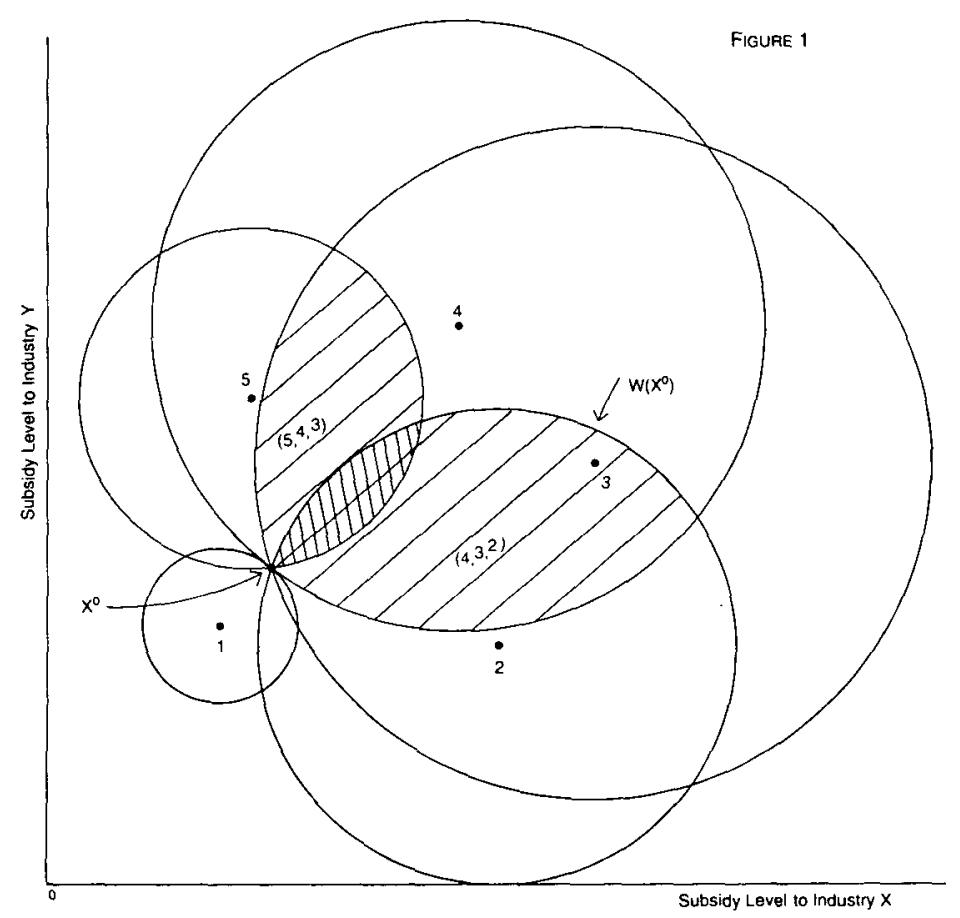

21. The first results of this type were proved in Kramer, supra note 16 and Shepsle, supra note 16. See Appendix for the relevant formal developments. 
ranked above all others. For simplicity, all legislators are presumed to have circular indifference curves over the policy space $X$. This means that points further away from the ideal point are less preferred than points closer. The ideal points of legislators are labeled 1 through 5 , respectively. No majority rule (i.e., global) equilibrium exists in this setting. Let $x^{0}$ be the status quo policy (i.e., status quo level of subsidy). Then $W\left(x^{0}\right)$ is the set of policies that command a majority of votes against $x^{0}$. To find the location of this set, indifference curves for each of the legislators are drawn through the status quo. A given legislator prefers all points inside his indifference curve to $x^{0}$ and will therefore vote for these alternatives against $x^{0}$. The numbers inside regions indicate which legislators prefer points in this region to $x^{0}$. Any point located inside the indifference curves of three or more legislators is in $W\left(x^{0}\right)$ : The entire set, $W\left(x^{0}\right)$ is the interior of the diagonal-lined region.

Which point (if any) of $W\left(x^{0}\right)$ might replace the status quo crucially depends upon the makeup of the committee jurisdiction. To see this, suppose the committee with jurisdiction is comprised of a single individual. If legislator 1 gains control, for example, then $x^{0}$ remains an equilibrium since no point preferred by 1 to the status quo is within $\mathrm{W}\left(\mathrm{x}^{0}\right)$. If, on the other hand, 3 gains control, then a large change in the status quo is made. Since 3 's ideal point is contained within $W\left(x^{0}\right)$, he may propose, and the legislature will pass this point.

This example illustrates the general results about the nature of structureinduced equilibrium. Because the legislative rules institutionalize the agenda control in a fixed nonrandom manner, some point $x^{*}$ may remain a stable legislative choice. Even though there exists a set of points that command a majority against $\mathrm{x}^{*}$, as long as the committee prefers $\mathrm{x}^{*}$ to all points that beat $\mathrm{x}^{*}$, it remains in effect. Moreover, the example also shows that $\mathrm{W}\left(\mathrm{x}^{0}\right)$ may allow considerable latitude in the nature of final policy. It is in this sense that committees gain a disproportionate influence over policy choice within their jurisdictions and why we look to committees to understand policy choice in any specific area. Once the committee makeup is known, then the structure-induced equilibrium is determinant and characterized for any given status quo and corresponding set $W\left(x^{0}\right)$.

\section{Implications for Regulatory Behavior}

Having presented the model of equilibrium policy choice for a committee system, we now develop the implications for regulatory agency policy making. The model implies a structure-induced equilibrium policy exists-that is, a stable policy-for each regulatory agency. The agenda control rules (A2) and the agency control authority (A3) allow committee members to protect a given policy equilibrium to the benefit of their constituency or clientele. This process, repeated across many policy areas, gives rise to the notion of subgovernments described above.

For a particular policy area, characterizing agency decisions depends upon the nature of the politically active constituency groups. These groups represent demands for certain types of policies and against others and, therefore, provide the reward structure for political action. Inactive interests, on the other hand, remain unrepresented because they do not provide rewards. A second distinction, noted 
above, is that congressmen weigh the interest of their own district more heavily, ceteris paribus, than those interests outside their constituency.

Recalling that agencies are assumed to be controlled by congressional committees, the following implications can be derived from these two distinctions. First, if local constituency interests dominate the committee, these receive the benefits of regulation, subject to the constraints imposed by the majority rule constraint set. Thus, the single-policy issue committee-such as agriculture, urban programs, western land policies-are strongly biased in favor of these locally represented constituents.

Second, if the issue is not locally important, that is, if the active interests are, by and large, not from districts represented on the committee, then committee members look for the greater political return, given the (possibly diverse) set of interests that follow this issue. Thus, if only one major constituency is politically responsive on this issue, policy is biased in its favor. Because the politically relevant interest groups are limited, the lack of political response limits the benefits to the committee from choosing otherwise, while the negative returns impose costs since support is potentially lost to opponents. On the other hand, if two constituencies are active, policy reflects a compromise between these interests. Here again, if some interests remain inactive, providing little rewards, they remain unrepresented and hence at best receive no benefits of policy and may well bear some (or most) of the costs.

Finally, a third implication of this equilibrium is that once clientele relationships have been established, committee members will attempt to protect them. Status quo clientele relationships will be given up only when the expected political returns from severing existing relationships and gaining new ones are higher than the losses imposed from losing current ones. Thus, if a new constituency begins to arise, perhaps gaining voice through various politicians (not on the relevant committee), policy will remain unchanged initially. Attempts by other politicians to alter policy will be resisted.

The history of the ICC throughout much of this century illustrates each of these predictions. ${ }^{22}$ For the first third of the century, the railroads were the major active constituency, receiving the benefits of state-imposed cartelization. When, in the late 1920s, the advent and success of motor transport threatened cartelization, truckers were brought within the bounds of regulatory control during the depression in 1934. As the second implication above predicts, this compromise benefitted the two active groups through the extension of the cartel to include trucks; since rail regulation remained a low saliency issue throughout most of this period, the relatively inactive consumer interests remained unrepresented and unrewarded.

During the post-World War II era, until very recently, these remained the major active interests in surface transportation policy, and therefore the major

22. This summary draws on the wealth of empirical studies on the ICC. For example, P. MACAvoY, Economic Effects of Regulation (1965); J. Meyer, M. Peck, J. Stenason \& C. Ziwick. The Economics of Competition in the Transportation Industries (1959); and Moore, Deregulation Surface Freight Transportation, in Promoting Competition in Regulated Markets (Phillips ed. 1975). 
beneficiaries of regulation. ${ }^{23}$ This state of affairs was by no means natural or self-maintaining. On several occasions, the congressional committees with jurisdiction were forced to protect this equilibrium from outside influence. First, throughout the entire period, the appointments process continued to select commissioners primarily on the basis of their acceptability to regulated industries. ${ }^{24}$ This helped maintain the agency's position in the subgovernment. Second, when the Justice Department seriously threatened the cartel's legal basis by moving against the ICC rate bureaus for collusively setting rates, Congress stopped it. In 1948, it passed the Reed-Bulwinkle Act exempting the ICC from the antitrust laws, thereby unambiguously preventing the Justice Department from upsetting the status quo policy equilibrium.

Finally, nearly every president during the postwar period has tested the water (i.e., assessed the potential political returns from further action) on regulatory reform in general and transportation policy in particular. Truman, whose administration developed the forestalled antitrust action against the ICC, assembled the first Hoover Commission to study regulatory policy; Eisenhower gathered the second. Kennedy employed Judge Landis who developed the oft-cited Report on Regulatory Policy to the President-Elect. Kennedy, unlike his predecessors, further tested the political climate for further action before abandoning the effort. Nixon set up the Ash Council; and finally, both Ford and Carter have called for reform and deregulation. While all were critical of the industry-specific regulatory agencies, none, except Ford and especially Carter, set in motion further action because most judged the returns too meager. The single most important difference between the early period of stable policy and the events in the late 1970s leading to deregulation was the lack of political returns for action: no audience cared about or favored reform. In the mid and late 1970s, one appeared.

The main implication of the equilibrium theory developed here is that policy remains stable and beneficial to congressional-agency clientele as long as the relevant variables of public opinion, balance of power of interest groups, presidential initiative, and precedential legal decisions are stable. As long as these variables remain constant, the political rewards from various alternatives remain constant. Consequently, both congressional electorally-induced preferences and majority rule constraints set are constant as well, thereby leaving the structure-induced equilibrium in effect. Stability in the political reward structure implies that agencies may appear committed to serving a particular clientele for long periods of time.

While the above summary of the ICC developed the interpretation of the model for one agency, similar explanations for other agencies and their clientele could also be pursued. This same process of subgovernment operation is repeated in different guises throughout many areas such as agriculture, urban, and environmental policies, public works, defense procurement, and so on. This list could be

23. Minor exceptions to this broad statement include passenger rail service, particularly along the Eastern seaboard commuter routes.

24. See Kohlmeier, supra note 10 , ch. 5 at 53-68, ch. 7 at $83-104$, ch. 11 at $145-51$, ch. 12 at $152-59$, and Committee on Congress, supra note 9 .. 
extended almost indefinitely as the number and diverse nature of policy areas and their relevant clientele is quite extensive.

\section{Equilibrium Change: The Comparative Statics of Regulatory Policy}

The model developed in Section I characterizes regulatory policy equilibrium based on stable patterns in the relevant independent variables. However, as these variables begin to change, regulatory policy may also change to a new equilibrium. Section II investigates the influence of several types of changes that have thus far been assumed constant. The variables studied here are: interest group power or composition; congressional structure; precedental court decisions; the president's policy program; and the economic analysis of regulatory policy. In each case, the underlying issue is whether the relevant change of the particular variable manages to intercede in subgovernment operation.

Three case studies comprise Section II: the recent deregulation of airlines by the $\mathrm{CAB}$, a contrast between broadcast regulation and telephone regulation by the FCC, and finally, the nature of the influence of the environmentalists on nuclear power. The discussion takes the following form. In each case, the effects of the relevant changes in variables at a relatively abstract level are explored. Then, these predictions are applied to the particular course of events. These applications are offered for the understanding of regulatory choice in a political process rather than as tests of the model.

\section{A. Deregulation of Airlines}

Three separate, though mutually reinforcing effects are relevant for deregulation of airlines: changes in public opinion and active interest groups; the influence of the president; and the effect of jurisdictional changes in Congress.

\section{Changes in Public Opinion and Active Constituents}

Interest groups have always played a major role in American politics. Over time, moreover, the nature and composition of interest groups has changed. As interest group activity changes, so do the demands upon politicians for various types of action. Just as in a market where changes in the composition of demand for a mix of products invokes a supply response, so too does the political system respond to changes in interest groups. While the model does not account for changes in the composition of interest groups, it yields considerable insight into the policy response which subsequently follows.

Most students of the regulatory process have appreciated the significance of interest groups for regulatory policy. Less well understood, however, have been the implications of different types of changes in the relative mix of important interest groups. Examples include a change from one major producer group to two, somewhat opposed, sets of producers (e.g., trains versus trucks in ICC); or regulation may pass through a period in which solely producer groups are active to one in which some nonproducer group intervenes (e.g., the environmentalists intervention in nuclear power regulation by the $A E C$ ). 
Consider a regulatory arena in which producer groups are the sole active constituents. As such, they are the sole group generating political rewards and, hence, are the main subgovernment clientele. Suppose that public opinion on this issue changes so that a large segment of the public (though not necessarily a majority) now responds politically on this issue. Some enterprising politicians may see it in their interests to try to respond to this change by calling for changes in regulatory policy as well as active opposition to the otherwise stable subgovernment.

The crucial political actors, however, are those on the committee with agenda power over the agency. The rise of political opponents to the current subgovernment arrangements does not necessarily guarantee a forthcoming policy change. These opponents must influence the committee. Their avenues are twofold. First, they raise the political costs for the committee of certain actions to influence and control agency policy. For example, by actively opposing what would otherwise be an unopposed and uncontroversial commission appointment, the costs of vetoing opponents of the current regulatory regime are higher. This is particularly true when the president and his appointees are allied with the opponents. ${ }^{25}$ Second, changes in politically active constituents may also change the committee members electorally induced policy preferences. If the potential rewards from serving the new constituency outweigh the current rewards from continuing to benefit current clientele groups, then the key committee members will use their legislative proposal powers to affect a change given the new payoffs and the majority rule constraint set. Moreover, the greater the response among new participants, the more likely policy gains (through compromise or policy reversal) are forthcoming.

\section{Presidents (and Other Political Entrepreneurs)}

A political entrepreneur is a politician who seeks to change the issues within the current public debate, and in so doing becomes credited with this effort and with subsequent policy initiatives. ${ }^{26}$ Developing a clientele or support coalition is crucial to success of this role since this provides the ultimate political rewards. A political entrepreneur may successfully alter the status quo operation of a subgovernment agency-clientele relationship under certain circumstances. ${ }^{27}$

Consider a president undertaking this role. A president's influence over policy is limited, and like any scarce resource, must be conserved. Therefore, he reserves this power for his highest priority areas such as new policy initiatives rather than

25. See subsection infra.

26. While a variety of motivations may underly the development of this role, these have similar consequences for our purposes: ambition for higher office or a place in history, greater success at building a clientele and maintaining electoral position, or simply the desire to implement some strongly felt policy position. For the development of the implications of political entrepreneurs, see N. FroHLICH \& J. Oppenheimer, Mod. Political Econ. (1978); Salisbury, An Exchange Theory of Interest Groups, 13 Midwest J. Political Sci. 1 (1969); and Wagner, Pressure Groups and Political Entrepreneurs: A Review Article, Vol. I, Papers on Non-Market Decision Making (1966) (Public Choice)

27. In what follows, the discussion focuses on the president who is perhaps most easily recognized in this role. Other figures include prominent members of Congress associated with a particular policy area as well as major figures outside the public sector (for example, Martin Luther King on civil rights, George Meany on labor legislation or Ralph Nader on consumer issues). 
intervention in on-going regulatory programs. ${ }^{28}$ However, when such an area becomes a high priority item on a president's agenda, it has specific consequences. By publicizing an alternative policy position and drawing public attention, he threatens to raise costs to those seeking to protect the status quo. Particularly when this move is combined with a change in public opinion or the relative composition of active interests, it may hinder congressional protection of an equilibrium and develop pressure for new policies (as discussed above). Congressmen normally veto entrepreneurial commissioners who seek to implement new policy programs that upset the current clientele relationships. By bringing the area into the public forum, the president may increase political costs to committee members exercising their veto power. This avenue of influence is particularly attractive when a president may fill several vacancies on a single commission in a short period of time. By giving a regulatory commission's chairman (and majority) an independent political base and protector, the president may potentially attenuate the normal operation of subgovernments and congressional (and agency) protection of status quo clientele relationships.

Once again, however, it must be emphasized that the president's ability to engineer these moves is limited. The area must be a high priority item on his policy agenda. And perhaps more important, there must be an audience or constituency for success. Without such, the political rewards for the president are few and his ability to affect the costs of congressional actions is diminished.

\section{Jurisdictional Changes}

Jurisdictional changes over ongoing programs are relatively rare in the Congress. The last major reorganization of committee jurisdiction, for example, took place in 1946 when the number of committees fell from 48 to 19 . A somewhat less significant change occurred in 1970 in the House and in 1975 in the Senate. On occasion, committees are added and jurisdictions reorganized as new issues come into the political forefront (such as energy issues in our current political era or consumer and environmental issues over the past two decades).

An even rarer event, however, is for one committee to successfully usurp jurisdiction over a particular agency or issue from another committee. To consider the effects of an alteration in committee jurisdiction when it occurs, refer to Figure 2. Let $\mathrm{Cj}$ be the committee with jurisdiction over issue $\mathrm{X}$, a one-dimensional policy space. ${ }^{29}$ The ideal points of the five legislators are $x^{1}, 2, x^{m}, 4$, and $x^{h}$ respectively. Presume, for convenience, that the committee members' ideal points are all in the neighborhood of $x^{1}$, and that the status quo is $x^{0}$.

28. As examples: For Kennedy this included the programs composing his "New Frontier;" for Johnson, it was the "Great Society" (in combination with the Vietnam War); for Nixon, it tended to be foreign policy issues. Interestingly enough, both Ford and Carter have included regulatory issues among their programs of personal interest.

29. While a simple one-dimensional example is presented, this principle can be generalized to more complicated, multidimensional jurisdictions. 


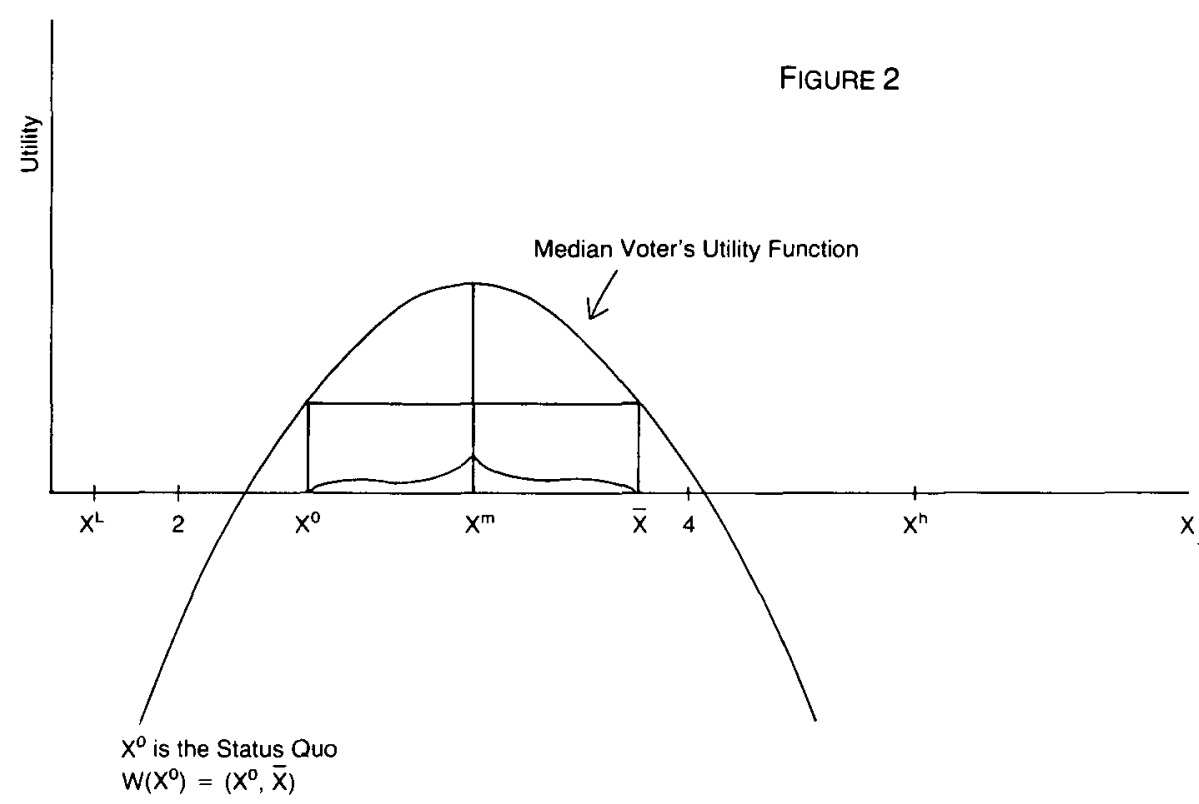

From the analysis described above, it is apparent that $x^{0}$ remains an equilibrium. The majority-constraint set, $W\left(x^{0}\right)$, is the open interval $\left(x^{0}, \bar{x}\right) \cdot{ }^{30}$ On the other hand, within this range, the committee prefers points further to the left to points on the right. Since no point to the left of $x^{0}$ commands a majority, and since the committee by assumption prefers $x^{0}$ to all points to the right of $x^{0}, x^{0}$ remains in effect.

However, it is also apparent that other legislators (in other committees) have different preferences and stand to gain from some alternation of the status quo. Suppose that some other committee, $C_{k} \neq C j$, attempts to take jurisdiction over regulatory issue $X$, and within the relevant range, $C_{k}$ prefers larger $x$ to smaller $x$, and that their ideal point is located at $x^{\mathrm{h}}$. If the change in jurisdiction takes place, the change in policy is completely predictable. Since the new committee unambiguously prefers larger $x$ to smaller $x$ within the majority-constraint set, $W\left(x^{0}\right)$, it will propose, and a majority of legislators will vote for, a point just smaller than $\overline{\mathbf{x}}$. This point defines the maximum change within the legislative constraints open to $\mathrm{C}_{\mathrm{k}}$.

Three further points are worth noting briefly. First, because frequent jurisdictional usurpation would destroy the incentive to specialize on committees, a number of parliamentary mechanisms in Congress explicitly forbid crossing jurisdiction lines. Nonetheless, this may still occur under unusual circumstances such as ambiguity or

30. To see this, note that the median voter's point is labeled $x^{m}$. As indicated on the graph of his preference function, this point yields the highest utility, and that, moving in either direction, he prefers all points closer to $\mathrm{x}^{\mathrm{m}}$ to those further away. Thus, any point between $\mathrm{x}^{\circ}$ and $\overline{\mathrm{x}}$ commands a majority against $x^{0}$ : the median voter prefers any such point (since, as depicted, $\bar{x}$ is equally preferred by the median voter to $x^{\circ}$ ); moreover, all voters with ideal points located to the right of the median prefer any such $x$. Since the latter comprise half of the voters by definition, a majority prefers $\bar{x}$ to $x^{\circ}$ when the median is counted. 
technicalities. ${ }^{31}$ Second, this example suggests the nature of the growth in intervention resulting from the change in committee chairmen from conservative southern democrats prior to the mid-1960s to the northern, interventionist-minded liberal democrats since the mid-1960s. Third, any attempt to change jurisdiction would certainly invoke a strategic response by the original committee to forestall change. However, an in-depth analysis of these possibilities is beyond the scope of this paper.

\section{Political Transformation of Airline Regulation, 1970-1978}

The influence of these three effects combined to foster deregulation of airlines. In late 1974 and early 1975, Senator Kennedy (D-Mass.) began public investigations of the practices of the $\mathrm{CAB}$, in part to determine the political support from further action on this issue. This investigation took place under the auspices of Kennedy's Senate Judiciary Subcommittee on Administrative Practice and Procedure. While this event served to advocate and draw public attention to an alternative policy (deregulation), little positive action resulted because Kennedy had only investigatory powers but no legislative jurisdiction over the CAB. Jurisdiction over aviation lies with the Senate Commerce Subcommittee on Aviation chaired by Senator Cannon (D-Nev.), a staunch opponent of deregulation at this time. Indeed, as one observer noted, "Kennedy's $\mathrm{CAB}$ reform ideas have been greeted with stony silence," by the senators with jurisdiction over the CAB. ${ }^{32}$

By mid-1976, however, Cannon's opposition was no longer complete. Kennedy had continued popularizing deregulation, including a second set of hearings in late 1975 and the release of a major study in February 1976, with considerable public impact. President Ford also came out in favor of reform, thereby forming a bipartisan coalition. More surprising, however, was the move on the part of the Senate Commerce Subcommittee Chairman, Cannon. While criticizing Kennedy for encroaching on his subcommittee's jurisdiction, Cannon nontheless began advocating more competition for the airlines. Reflecting a further shift in early 1977, Cannon and Kennedy jointly sponsored a measure to deregulate the CAB. By early 1978 the situation continued to move away from the status quo. President Carter advocated deregulation, appointed several new, enterprising, deregulation-minded members to the CAB. In the fall of 1978, Congress passed the Airline Deregulation Act.

What accounted for the change in enthusiasm by Cannon? How did the change in the long-standing regulatory status quo come about? In order to answer these questions, consider the subgovernment operation prior to the sequence of events from 1974-1978, outlined above. The subgovernment had functioned smoothly for years. The airlines were the major clientele group of the Board. Moreover, as

31. Kennedy's subcommittee had jurisdiction over administrative practices of federal agencies, allowing jurisdiction over agency procedure but not policy. Thus, Kennedy was able to hold hearings on $\mathrm{CAB}$ policy under the $\mathrm{CAB}$ "practices and procedure." However, his lack of policy jurisdiction prevented him from bringing new legislation to a vote without consent of the Commerce Committee.

32. See Kohlmeier, A Ripe Time for Airline Deregulation, NA'P J. 1458 (1975). 
predicted by the approach when outside developments threatened to alter the arrangement in the subgovernment, Cannon, as Aviation Subcommittee Chairman, moved to protect the status quo. For example, when the Post Office Committee engineered a transfer in control over award and compensation for airmail transport from the $\mathrm{CAB}$ to the postal service as part of the postal reorganization, Cannon successfully asserted jurisdiction over the issue that forced the objectionable part of the proposal be removed. ${ }^{33}$ Cannon's initial response to Kennedy's action paralleled this earlier move. However, Kennedy managed to maintain authority for investigation (though not legislation) on the basis of a technicality. ${ }^{34}$

Prior to the rise of deregulation, the major issue centered upon the adequacy of service to small communities. ${ }^{35}$ Restrictions on competition simply were not an issue. In part, the politics of airline regulation at this time rested on a fundamental asymmetry. Disruption of service was highly visible and a significant issue while lost opportunities for fare reductions drew little attention. Since increasing competition risked greater chances of financial problems and service disruption with little promise of political reward, it was avoided.

Figure 3a depicts this situation with reference to a single dimension, the degree of subsidization of service to small communities. While price, route, and entry decisions had been demonstrated by economists to have a negative impact on consumer welfare, these were yet to become political issues. The status quo represents the structure-induced equilibrium based on the current political opportunities of the committee. The set of policies that beat the status quo is labeled $\mathrm{W}\left(\mathrm{x}^{0}\right)$. Cannon and the Aviation subcommittee's major concern was adequacy of service; service to small communities was encouraged within the feasible limits.

Kennedy investigations began at this point, in 1974. The policies initiated in the previous few years, under the leadership of Nixon appointee, Chairman Timm, had generated controversy and denouncement by both the airlines and Congress. Kennedy's efforts gained publicity by uncovering a series of scandals. The public reaction, however, was more than a reaction to scandal. Unlike previous investigations of regulatory failure initiated by a series of presidents, the Kennedy hearings generated a political response, warranting further efforts. In 1975 and 1976, President Ford aided the cause by calling for reductions in regulation, further

33. For a discussion of this policy issue and its resolution that is compatible with the model of committee agenda control developed above. See Levine, Regulating Airmail Transportation, 18 J. L. \& EcON. 317-59 (1975) [hereinafter cited as Levine].

34. See note 31 , supra.

35. Among the many published hearings relating to the adequacy of air service, see Adequacy of Air Service: Hearings Before the Subcomm. on Transportation and Aeronautics of the House Comm. on Interstate and Foreign Commerce, 91 st Cong., 1st Sess. (1969); Adequacy of Scheduled Air Service to the Nation's Small Communities: Hearings Before the Subcomm. on Aviation of the Senate Comm. on Commerce, 92nd Cong., 2nd Sess. (1970); Adequacy of Northern New England Air Service: Hearings Before the Subcomm. on Aviation of the Senate Comm. on Commerce, 92nd Cong. 1st Sess. (1971); Local Air-Service to Small Communities: Hearings Before Subcomm. on Aviation of the Senate Comm. on Commerce, 92nd Cong. 2nd Sess. (1972); and Adequacy of Air-Service in Illinois: Hearings Before the Subcomm. on Aviation of the Senate Comm. on Commerce, 93d. Sess. (1974). See also Levine, supra note 33. The latter also contains a description of the jurisdictional concerns on this issue that fit precisely within the above formulation. 


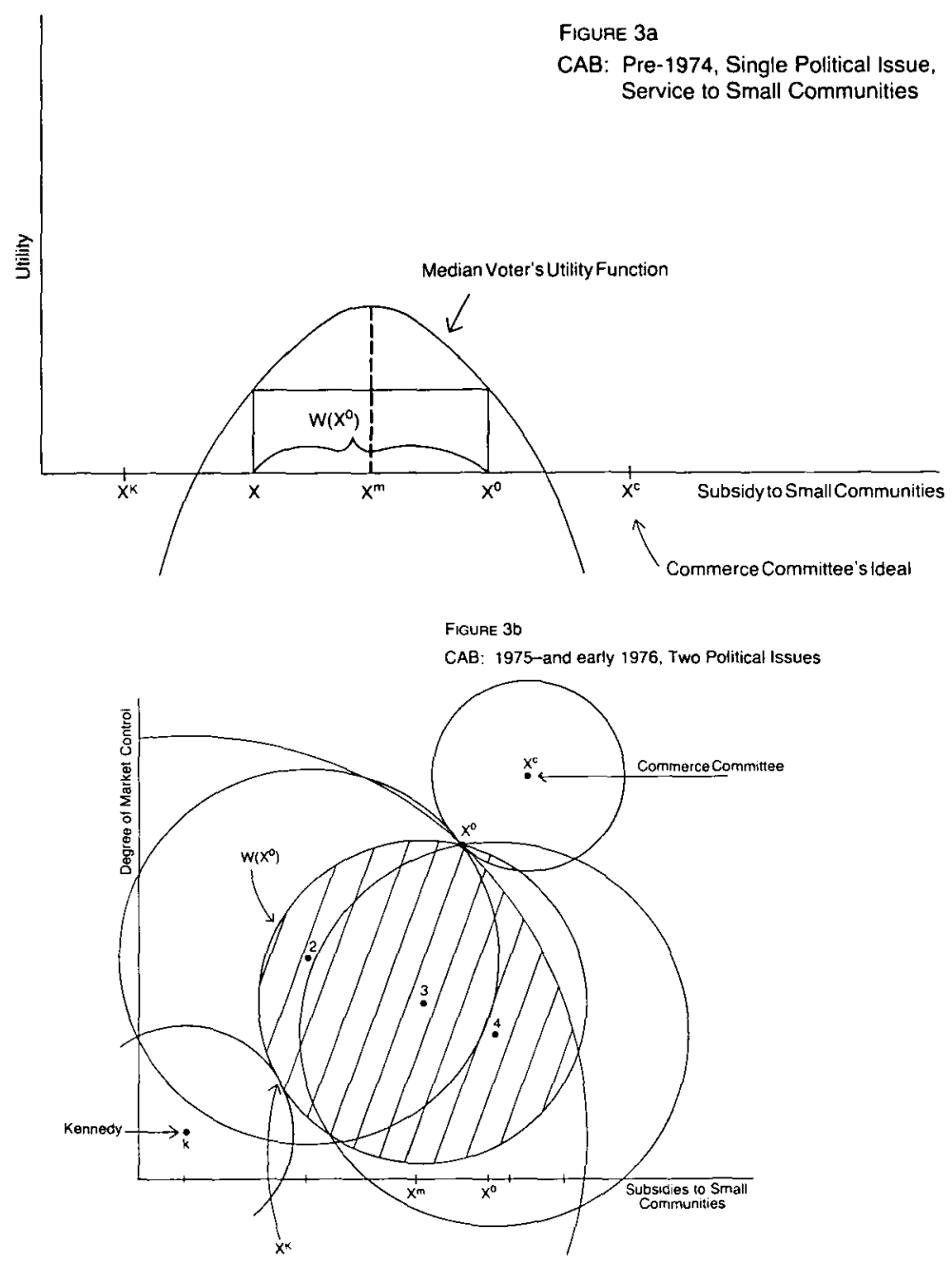

popularizing the issue, and appointing a reform-minded chairman, Robeson. ${ }^{36} \mathrm{~A}$ second set of Kennedy hearings, in late 1975, publicly demonstrated two things. First, the dissatisfaction with $\mathrm{CAB}$ policies was nearly universal (though not unanimous on the reasons). Nearly all participants criticized the Board, including the airlines themselves, who were dissatisfied over the recent CAB policies. Second, it demonstrated that the issue made good press.

In a rare political maneuver around the official committee, Kennedy had gained the upper hand. ${ }^{37}$ The political appeal of the issue as well as Kennedy's

36. While favoring reform, Robeson made no bold policy initiative during his term, though his advocacy of deregulation near the end of his term before the first set of hearings by Cannon represented a rare case of an agency head advocating its own abolishment.

37. As two political observers note, "A short time before, Kennedy had been an interloper in aviation issues. Now, suddenly, through a combination of diligent staff work, manipulation of the press, and sheer good fortune, Kennedy was the established spokesman on the most important issues that affected airline industry. Cannon had been neatly circumvented." R. JoNes \& P. Woll., The Private World of Conciress 69 (1979) [hereinafter cited as JoNes \& WOL.L.] 
timing and political maneuvering had taken all by surprise. Not only had Kennedy demonstrated the political rewards inherent from airline decontrol, but he was reaping them.

In terms of the model developed above, two aspects prompted action by Cannon. First, Kennedy (and others including Ford) had developed a new relevant issue and were demonstrating the strong appeal of a radical departure from the status quo. Without active intervention on the issue, Cannon might have lost control to Kennedy. Had Kennedy successfully taken over the issue (that is, gained jurisdiction), major changes would have passed. This is depicted in Figure $3 \mathrm{~b}$. Given the newly relevant political issue of degree of market control added to the older issues (represented as the unidimensional "subsidy level to small communities"), the status quo and corresponding majority constraint set are drawn. In early 1976, as the Figure depicts, the Commerce Committee with policy ideal $x^{c}$, still supported the status quo. Kennedy, depicted at K, supported significant changes to low subsidy levels combined with decontrol. The evidence suggests that most other senators were (or became over the next year) somewhat disposed toward decontrol, but were significantly concerned about service to their states (and/or the effects on labor groups). ${ }^{38}$ Hence, Figure $3 \mathrm{~b}$ locates the ideal points for three other senators favoring less control than the status quo, but nearly as much subsidy to small communities. In the event of a jurisdictional change, Kennedy would optimize over the majority constraint set, $W\left(x^{0}\right)$, by proposing $x^{K}$ which (to replace $x^{0}$ ) would pass the Senate.

Cannon, by taking up the issue, forestalled a jurisdictional fight; but the threat, combined with the new climate of public opinion, forced him to consider reform as serious issue. This move attempted to diffuse criticism and eclipse Kennedy. In early 1976, as Cannon began his own set of hearings, he unambiguously denounced decontrol.

Events favoring deregulation continued. Newly elected President Carter advocated reform early in his term. This was followed by a key event, the appointment by Carter (with the sponsorship of Kennedy) of a strong critic of regulation, economist Alfred Kahn, to the chairmanship of the Board. As shown above, the appointment of commissioners not in line with the status quo requires a separate source of political support, in this case President Carter and Senator Kennedy. In combination with the heightened publicity in 1977 (as opposed to pre-1974) their support increased the costs to congressional veto. Without the development of the new issue and strong support outside existing subgovernment, including presiden-

38. Regarding the preferences of other legislators, see the analysis in Cohen, Airline Deregulation is Not Yet Cleared for Take-Off, NAT'L J. 1193-5 (1977). She reports that, "the committee's review of the legislation pushed by Cannon (with Kennedy's support) demonstrate that most senators do not take the time to review or understand the broad arguments. Rather, they ask just one question: What does it do for my state? And in doing so, their concern is primarily responsive to local interests-airlines, unions, airport operators - that would be most directly affected by change." 
tial advocacy and support, Kahn was unlikely to have made it onto the Board, and protection of the congressional clientele would have continued. ${ }^{39}$

The new members at the $\mathrm{CAB}$ with external political support played a crucial role in the success of deregulation. By pursuing deregulation within the bounds of existing legislation, they performed an important "market test" for Congress. Had the attempt been unsuccessful, Congress would have denounced the Board and curtailed the decontrol program. But by 1978, hardly anyone was being hurt by the de facto move to deregulation. Indeed, fares were down and profits were up, clearly demonstrating that decontrol was not the dangerous, disastrous alternative that pessimists and protectors of the status quo had predicted. The real success of Kahn and his colleagues was twofold. First, by inventing a mechanism within existing laws, they avoided the need for new legislation prior to policy change; and second, they implemented change in a nondisruptive manner, demonstrating viability.

Given the nature of the new political issue, the success of the new policies under Kahn, Cannon approached deregulation with increasing enthusiasm. By the time the legislation came up for passage, the rewards clearly favored deregulation. Cannon became identified publicly with a new, publicity generating issue just a few months before his successful reelection in November $1978 .^{40}$ Note, however, that had this issue not generated public support (as it had not in the 1950s and 1960s), and if prominent political figures outside the subgovernment (Presidents Ford and Carter, and Senator Kennedy) had not vigorously pursued a change in policy, the subgovernment probably would not have faced radically differing incentives. ${ }^{41}$ Congress had the final say in policy choice: had not in 1978 decontrol appeared so successful, Congress would have undoubtedly instituted a more mild reform program.

\section{B. Regulation by the FCC}

The following discussion contrasts the course of regulation in protecting the status quo in two different regulatory responsibilities of the $\mathrm{FCC}$, regulation of over-the-air broadcasters and common carrier regulation of the telephone system. ${ }^{42}$

39. As Berman notes, "Had the political environment remained hostile to deregulation, as it always had been before 1974, pro-deregulation individuals almost certainly would have not been appointed to the agencies and it would have had both less political incentive and less ideological inclination to change policies." Berman, Civil Aeronautics Board, in WiLsoN, supra note 1, at 76.

40. For example, Cannon noted upon the passage of the Airline Deregulation Act, "I bring to the Senate today one of the most significant pieces of legislation in the past several decades. Important not so much by itself, but because it represents one of the only opportunities this body has had in recent years to vote for less government regulation and for more free enterprise for a major U.S. industry." JoNES \& WoLL, supra note 37 , at 72 .

41. As noted above, the presidential intervention alone probably could not have changed a subgovernment. A necessary condition for success seems the role of a politically active constituency supporting policy change with the president merely exploiting the underrepresentation in one area.

42. This summary draws on an extensive literature on the FCC, see R. NOLl, M. PECK \& J. MACGowan, Economic Aspects of Television Regulation (1973); Onex \& Brafuticiam, supra note 1 at ch. 5 at 121-57, ch. 7 at 195-237; Beson \& Crandall; Deregulation of Cable Television. 44:1 Law \& Contemp. Prob. 77 (1981); Coase, Federal Communications Commission, 2 J. L. \& EcoN. 1 (1959). 
In both cases, the major active political constituencies were the regulated firms. As such, these formed the relevant clientele group within the subgovernment, receiving congressional support and protection. In keeping with this, agency policy initiatives favored these groups.

In both cases, technological developments in the fifties and sixties led to competiton among regulated firms. As part of a subgovernment, agencies moved to protect existing arrangements. However, FCC policy differed radically. Competition fostered from the mid-1960s through the present for the telephone industry while competition with television broadcasters was stymied. In what follows, one factor that contributed to the divergence in regulatory paths on the two sides of the FCC is studied, namely, the influence of the courts. This illustrates how institutions outside a subgovernment may substantially influence the course of policymaking.

\section{Judicial Constraints}

Consider the influence of the court system on regulatory agency policy and the operation of subgovernments. In general, judicial decisions will be interpreted as constraints and changes in constraints placed on policy choice by agencies. Many distinct types of influences may alter policy. ${ }^{43}$

Suppose that a regulatory subgovernment is in operation, with the agencyclientele relationship on firm ground. Though the agency may seek to benefit its constituency, it may be restricted from doing so by the courts. For example, suppose that a new technology or new source of competition for regulated actors appears. The agency, following its incentives within the subgovernment, may attempt to establish jurisdiction over the new activity to protect its clientele. The success of this policy hinges critically upon court tests of jurisdiction and whether the court upholds or reverses the agency's decision. If the assertion of jurisdiction is upheld by the courts, then regulatory policy continues to be consistent with benefiting clientele; if courts overrule this move, new policy may be inconsistent with the old. Because courts lie outside the operation of subgovernments, their decisions may shape agency policy equilibrium in a manner that overrides subgovernment politics.

\section{Television Regulation}

In the 1950s, cable television was simply a supplement to over-the-air broadcasting of television designed to improve reception in the fringe areas where signals were weak. The virtue of cable was the provision of clear signals to remote areas. Throughout the $1950 \mathrm{~s}$, the issue remained uncontroversial and the FCC refused to assert regulatory jurisdiction over cable services.

43. A wide range of judicial interventions are important for regulation and each has a significant policy effect. These include judicial redefinition of mandate, judicial activism requiring a specific policy, and various forms of strategic manipulation by regulated actors, their opponents, or the agency itself to impose delay or raise costs. For the present, we study only one, judicial ruling on agency assumption of jurisdiction, and note that the other influences may be studied from a similar, comparative-statics analysis. 
By the 1960s, however, the situation changed radically as cable providers discovered they could compete with local stations in one market through importation of signals from another market via cable systems with microwave relays. In 1962, the FCC asserted jurisdiction over microwave relay systems employed by cable providers. Three years later, in a move to protect the status quo during 1965-66, the FCC imposed a freeze on all cable providers in the 100 largest television markets, forbidding importation of signals. These actions were challenged in the courts and were upheld, thereby allowing the assumption of regulatory authority to protect the status quo. ${ }^{44}$ Finally, in the early $1970 \mathrm{~s}$, a compromise was arranged between the broadcasters and cable providers, allowing limited growth of the latter. The important point here is the role played by regulation in delaying the growth of cable and the inhibition of competition.

The rise of a new technology that eroded the privileged position of regulated firms illustrates the reaction of a subgovernment to protect the status quo. The key congressman in broadcast regulation, Senator Pastore, favored protection of the interests of broadcasters. ${ }^{45}$ Though Congress gave the FCC no official legislative guidance, none was needed. The agency reacted by implementing policies highly favorable to its clientele.

\section{Telephone Regulation}

In contrast to the protection of the regulatory status quo by inhibiting the competition from cable TV, the FCC has encouraged competition with the onetime monopoly provider of telephone service, American Telephone \& Telegraph (AT\&T). Technological developments have lead to two distinct areas of competition with AT\&T. These have followed similar courses: competition in certain long distance markets from microwave telephone companies, and competition from alternative providers of various terminal devices. Though both have followed similar courses, only the latter will be discussed.

In the mid-1950s, the domestic phone service prohibited customers from utilizing terminal equipment not provided by AT\&T. The ostensible rationale for this restriction was that "foreign attachments" not manufactured and installed by AT\&T could potentially harm the entire system through interference or incompatability. This rule was challenged in 1955 by Hush-a-Phone, the manufacturers of a device attached to the telephone mouthpiece to reduce the amount of background noise picked up by the phone and transmitted over the line. The FCC ruled in favor of $A T \& T$, protecting the status quo. As in the case of cable, the regulatory decision was challenged in the courts, this time with opposite results. In 1956, the Court of Appeals for the District of Columbia reversed the FCC restriction of competition, ruling that in this case the device did not adversely affect the phone system. ${ }^{46}$ The FCC subsequently reversed its policy.

44. United States v. Midwest Video Corp., 406 U.S. 649 (1972); United States v. Southwestern Cable Co., 392 U.S. 157 (1968).

45. See, e.g., the analysis in Krasnow \& LaNciley, supra note 10.

46. Hush-a-Phone Corp. v. United States, 238 F. 2d 266 (D.C. Cir. 1958). Here, the court ruled that 
A decade later, the issue was brought before the FCC again in the landmark Caterfone decision. ${ }^{47}$ This case concerned the right of individuals to use terminal devices that allowed phone communication with mobile sources using the Caterfone device. Again, AT\&T opposed the competition. However, in this case, the Commission found that the device did not adversely affect the phone system. The judicial precedents in the Hush-a-Phone decision were clear. As Owen and Braeutigam note, "the Caterfone case reaffirmed the Hush-a-phone principle, allowing entry into the supply of terminal equipment." 48 This decision insured that the market for terminal devices was open to competition.

The influence of the judicial system, considered a constraint on subgovernment operation, played a significantly different role in the terminal devices than in broadcasting. In both cases, the FCC asserted its regulatory authority to protect its subgovernment clientele. However, the imposition of constraints by the courts differed radically, upholding the regulation of cable while denying the prohibition of terminal devices. This single difference in judicial precedent provided the foundation for radically divergent policies from two sets of similarly motivated policy decisions by a single agency.

\section{Nuclear Power Regulation and the Environmentalists}

The agencies studied above involved a major political transformation leading to deregulation at the $\mathrm{CAB}$ and the promotion of competition by the FCC. However, the model is more general than a theory of deregulation. It also provides an interpretation of the intervention of one interest group into the on-going subgovernment dominated by another clientele group. The case of the influence of the environmentalists over the course of nuclear power provides an instructive application to explain agency policy change.

Following World War II, the United States embarked on a program of the peaceful applications of atomic power. The development of a nuclear power industry with electrical generating facilities was a major component of this program. The subsidies doled out by the AEC from 1946 fostered the development of its own clientele, the nuclear power industries, including vendors, uranium miners, as well as utilities seeking a cheap source of a power generation.

Two decades later, the deployment of these plants raised considerable controversy. Through this period to the present, the environmentalists sought to curtail or halt the deployment of nuclear facilities across the country as part of their broader goals of limiting access to the environment. The discussion that follows analyzes one small, but significant, piece of this complex regulatory arena, the delays imposed by the passage of the National Environmental Policy Act of 1969.

Beginning in the late $1960 \mathrm{~s}$, environmentalists became a regular source of

the restriction was an "unwarranted interference with the telephone subscriber's right to reasonably use his telephone in ways which are privately beneficial without being publicly detrimental." Id. at 269 .

47. In the Matter of the Use of the Caterfone Device in Message Toll Telephone Service, 13 FCC 420 (1968).

48. Owen AND Braelticin, supra note 1 at 231. 
intervention in nuclear power license proceedings, attempting to change the promotional aspect of nuclear power licensing. ${ }^{49}$ Among the diverse strategies of influence, including contesting applications at the AEC (after 1974, the NRC) and strategic use of the courts for delay, was the influence imposed by the environmental impact statements. Following the Calvert Cliffs ${ }^{50}$ decision in 1971 in which the court ruled that NEPA indeed applied to the AEC, environmentalists gained a small success. According to one study, ${ }^{51}$ the application of NEPA alone increased the price of nuclear facilities by 10 to 15 percent. ${ }^{52}$ Since the issue throughout the 1970s regarding nuclear power was the cost escalation, ${ }^{53}$ this contributed the trend away from nuclear power toward other sources of baseline power generation. While affecting nuclear power remained only part of the motivation for the enviromentalists' support of NEPA, the nature of its influence can be understood through the following analysis.

Consider two relevant sets of issue dimensions. $\mathrm{X}$ describes those relating to nuclear power directly, with larger $\mathrm{x}$ implying greater rates of nuclear power promotion by the goverment and the AEC. Second, and arising somewhat later than the programs concerning the first, $\mathrm{Y}$ describes issues relating to environmental protection. Greater y implies greater environmental protection. Suppose that a program for nuclear power development began earlier and located at $x^{\circ}$. In time, the second issue became relevant. Moreover, suppose that those favoring high environmental protection also favor low nuclear power, while those promoting nuclear power care considerably less about environmental protection. Finally, assume that the frequency of deployment of nuclear facilities is a function of both environmental protection and nuclear power promotion, where greater $\mathrm{X}$, ceteris paribus, implies greater rates and where greater $\mathrm{Y}$, ceteris paribus, implies small rates.

Figure 4 describes the Congressional choice situation with $x^{0}$ as the status quo representing a high level of nuclear power promotion, but a low level of environmental protection. The preferences of five legislators are drawn with the members of the Joint Atomic Energy Committee represented to the right and below $\mathrm{x}^{0}$, with the environmentalists in the upper left, and the three other legislators in between.

49. For further study of nuclear power regulation, see I. BLPP ANI J. DerIAN, LICAHT WATER: HoW THE Nuclear Dream Dissolved (1978) [hereinafter cited as Bl py \& Deriaid]; D. MoNiciomery \& J. Quirk, Cost Escalation in Nuclear Power, in Perspectivfs on Exkrgy (M. Firebaugh ed. 1979) [hereinafter cited as Montcomery \& Quirk]; Cohen, Innovation and Atomic Energy: Nuclear Pouler Regulation 1966-Present, 43:1 Law and Contemp. Prob. 67 (1979); L. Cohen, Costs and Benefits of Nuclear Regulatory Procedures, 1979 (mimeo from Harvard University)

50. Calvert Cliffs' Coordinating Comm., Inc. $v$. Atomic Energy Comm'n.. 449 F.2d 1109 (D.C. Cir. 1971).

51. Direct construction costs of nuclear facilities more than doubled between 1971 and 1973 . It is estimated that roughly 15 percent of this increase resulted from environmental, safety-related changes in plant design mandated during this period. See Atomic Energy Comm'n., Power Plant Costs: Current Trends and Sensitivity to Economic Parameters (Washington 1345, 1974); Cohen, Innovation and Atomic Energy, 43:1 Law \& Contemp. Prob. 67 (Winter-Spring 1979).

52. See Bupp \& Derian and Montcomery \& Quikk. supra note 49.

53. For example, see V. Key, Politics, Parties axd Presslerf. Grolps (1964); and G. McCoxineli., Private Power and americian Democraci (1966). 


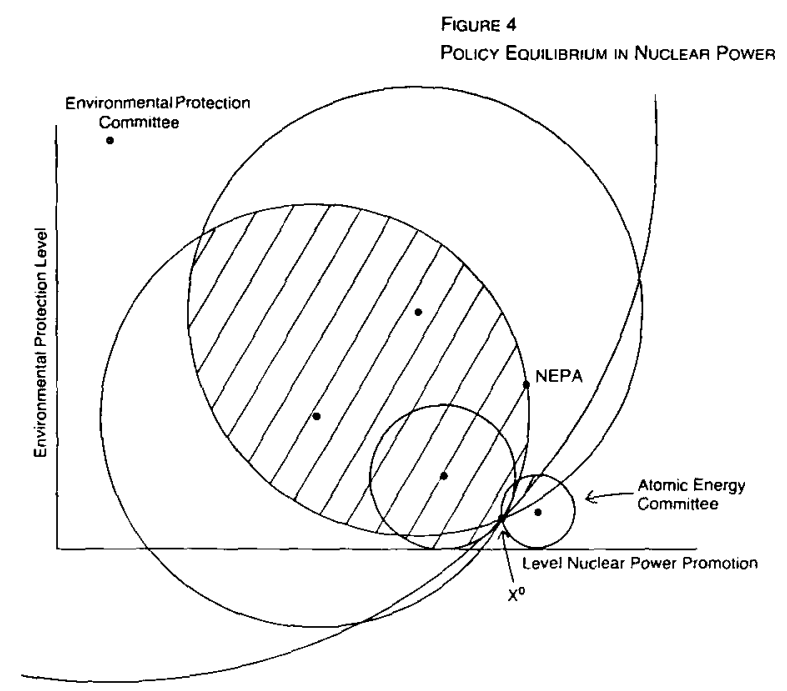

The shaded set $W\left(x^{0}\right)$ depicts the set of policies that beat the status quo. An interesting variant on the committee problem occurs here: the committee with jurisdiction over dimension $\mathrm{X}$ differs from that in control of dimension $\mathrm{Y}$, even though both significantly influence the ultimate outcome of a single regulatory activity.

Specifically, if the environmental protectionists in the upper left (of Figure 4) have jurisdiction over $\mathrm{Y}$ and the nuclear power promoters have jurisdiction over $\mathrm{X}$, then at $\mathbf{x}^{0}$, the nuclear power promoters can make no improvements. However, those in control of $\mathrm{Y}$ can command a majority of votes moving from $\mathrm{x}^{0}$ to $\mathrm{x}^{\mathrm{NEPA}}$, implying both a much greater level of environmental protection and a lower level of nuclear power deployment.

This example illustrates the same general principle throughout the paper. In order to affect decisions in a subgovernment, some political relationship therein must be altered, or circumvented. Here, the environmentalists gain influence not because they "capture" the AEC; to the contrary, the AEC and its supporters in Congress, if anything, grow more hostile to these influences. Rather, they gained influence because of their control over some alternative policy jurisdiction that significantly influenced the course of decisions chosen within the original subgovernment.

\section{Conclusion}

The fragmentation of policymaking by the committee system fosters the development of the relatively stable subgovernment alliances between the congressional committee with policy jurisdiction, the regulatory agency, and the clientele group(s). Each committee (and especially each subcommittee) controls a small number of policy issues. Correspondingly, nearly every major politically active group (or set of groups) is represented on some subcommittee. This fragmentation that parallels the major groups allows the simultaneous influence of many groups, each over a small policy domain, in a way not anticipated by Peltzman's model of a single 
political actor. If many different interests had to compete over a single policy domain, no single interest could dominate. More likely, policy would represent a balance of these interests based on the relevant political returns generated by each faction. Policy fragmentation into relatively autonomous subgovernments forestalls the need for this competition and suggests why policy benefits each within a small domain.

As we have seen, subgovernments develop stable relationships leading to policy choice benefiting the relevant interest groups. Each party of the subgovernment has incentives to participate and maintain these relationships. However, as shown in Section II, a number of events outside the control of these three parties may substantially alter the course of policy. Changes in court precedent may radically redefine policy. Changes in interest groups alter the incentives for politicians and may therefore result in policy change to reflect the new balance of interest groups.

To conclude, let us return to the seeming incongruity of the trend of deregulation amid increasing social regulation. In large part, these two trends reflect changes in the relative composition of interest groups in our society over the last thirty years. As recently as fifteen years ago, political scientists could subsume the entire range of active interest groups under three separate and nearly inclusive headings: business, agriculture, and labor. ${ }^{54}$ Throughout the thirty years following the inception of the New Deal in 1932, interest groups could be fit readily within this categorization. Since the mid-1960s, however, this has changed. We have witnessed the rise and prominence of single-issue groups as never before. These include the environmental, consumer, and civil rights groups, as well as the anti-Vietnam War protesters, pro- and anti-abortion groups, the tax limitation movement, and so on. This change has been paralleled by changes in the committee system so that jurisdictional lines parallel major groups. Similarly, party discipline has declined as individual congressmen are increasingly identified with an independent policy area. This structural change has allowed greater influence by these single issue groups in precisely the manner illustrated above in the AEC environmentalist example.

This process has had two effects. First, it has fostered and supported the new wave of regulation. The rise of the new interest groups such as the environmentalist, the consumerists (and the so-called public interest advocates), the civil rights activists and the affirmative action groups, have all contributed to a host of new regulations over the past decades. Second, it has resulted in the decline in political support for the status quo as the older pattern of interest groups becomes less relevant. Simply put, new groups are replacing the older groups as congressional clientele.

One simple example illustrates this process. Ralph Nader and his associates, as well as Senator Kennedy, couch their arguments against older economic regulation (e.g., the $\mathrm{CAB}$ or professional self-regulation) in a manner similar to an academic economist. ${ }^{55}$ This is certainly not because they are persuaded by the economic view

54. For a stimulating analysis of the policy consequences of the rise of single issue groups, see $M$. Fiorina, The Decline of Collective Responsibility in American Politics, 1980 (Working Paper No. 59, Center for Study of American Business, Washington University).

55. See The Monopoly Makers (1971). 
of the world. The policies they advocate in the safety, health, and consumer areas demonstrate the divergence in their views from those of economists. Rather, the empirical and theoretical development by economists is simply the easiest and most convincing manner to pursue their political goals in the more traditional regulatory areas. Simply put, the political constituencies of both these political entrepreneurs favor social regulation while the older order of regulation benefits other interests from a previous era that are on the political decline. As noted above, both the AEC and $\mathrm{CAB}$ have been affected by this trend. Thus, the two seemingly incongruous developments of increasing social regulation and simultaneous deregulation of certain older regulatory areas are really two manifestations of the same underlying trend, namely the changing basis of interest groups and representation in the Congress.

\section{APPENDIX}

This Appendix presents the formal results on the existence of a structureinduced equilibrium described in the body of the paper. ${ }^{56}$ This develops the precise contexts in which the results hold as well as other aspects of the model only alluded to in the text.

\section{The Model}

The basic results of social choice analysis of majority rule show that the conditions necessary for the existence of an equilibrium policy choice are unlikely to be met. Let $\mathrm{N}$ be the set of legislators, where each legislator, $i$, has an electorally induced preference relation, $\mathrm{R}_{\mathrm{i}}$, that is a complete ordering over the policy space $\mathrm{X}$, an open convex subset of m-dimensional Euclidean space. Let $C(x, y)$ be the majority rule choice function, defined over pairs of alternatives as follows. $x$ is said to be the majority rule choice when compared with $y$, i.e., $\mathrm{x}=\mathrm{C}(\mathrm{x}, \mathrm{y})$, if and only if $|\mathrm{M}(\mathrm{x}, \mathrm{y})|>|\mathrm{M}(\mathrm{y}, \mathrm{x})|$ where $\mathrm{M}(\mathrm{x}, \mathrm{y})=\left\{\mathrm{i} \varepsilon \mathrm{N} \mid \mathbf{x} \quad \mathrm{P}_{\mathrm{i}} \hat{\mathrm{y}}\right\}$ where $\mathrm{P}_{\mathrm{i}}$ is the $\mathrm{i}^{\text {th }}$ legislator's preference relation. A majority rule equilibrium is an $\mathrm{x}$ such that $\mathrm{x}=\mathrm{C}(\mathrm{x}, \mathrm{y}) \quad \forall \mathrm{y} \varepsilon \mathrm{X}$. In general, no equilibrium exists. Rather, for any particular point, there exists a set of points that command the support of a majority against it. Cycles exist as a result, and can be shown to extend over the entire policy space. ${ }^{57}$ Moreover, it can be shown in general that any point in the policy space can be the final result of the appropriately chosen agenda, or sequence of votes. ${ }^{58}$

The legislature studied in the paper is not a simple majority rule institution, however. Rather, legislators pursue their goals within the confines of the legislative committee system, described as follows. The set of legislators is divided into subsets called committees, $\mathrm{C}=\left\{\mathrm{C}_{\mathrm{i}}\right\}$ where $\mathrm{C}_{\mathrm{i}}$ is the $\mathrm{i}^{\text {th }}$ committee. Each legislator is a member of a particular committee. Committees play key roles in policy choice. Each of the

56. The model summarized in the appendix draws on Institutional Arangements and Equilibrium and Institutional Structure, supra note 16.

57. See notes 12 and 13 supra.

58. McKelvey, supra note 13. 
$\mathrm{m}$ dimensions of the policy space $\mathrm{X}$ corresponds to a political issue. The $\mathrm{m}$ issues provide the basis of the policy space are grouped into non-overlapping subsets called jurisdictions. Let $\mathrm{J}\left\{\mathrm{J}_{\mathrm{i}}\right\}$ be the set of jurisdictions, with $\mathrm{j}_{\mathrm{i}}$ the $\mathrm{i}^{\text {th }}$ jurisdiction. Committees are associated with their jurisdiction according to some fixed rule, $\mathrm{F}: \rightarrow \mathrm{J}$.

Within their jurisdiction, each committee is delegated agenda power. Any change in the status quo, $x^{0}$, within its jurisdiction must be proposed by the committee. This is the major difference between the legislative committee system and simple majority rule.

\section{Equilibrium Choice}

Consider a particular committee, $C_{j}$, together with its jurisdiction, $J_{j}=F\left(C_{j}\right)$. Let $\mathrm{Y} \subset \mathrm{X}$ be the subset of the entire policy space falling under $\mathrm{j}$ 's jurisdiction. The committee choice function, $C_{j}(x, y)$ defined over alternatives in $X$ reflects the preferences of committee members (or a decisive coalition of members) for policy states. As in the body of the paper, this committee is considered as a unit, dominated by a stable and decisive coalition. We therefore assume $C_{j}(x, y)$ is complete and transitive.

Let $x^{0} \in F$ be the status quo policy state. The results on majority rule noted above imply that for any given jurisdiction, and for any given status quo point, $\mathrm{x}^{0}$, there exist a set of points, $W\left(x^{0}\right)$, that beats the status quo in a majority rule vote. In the passage of new legislation to replace the status quo, the committee treats $W\left(x^{0}\right)$ as a constraint set, and chooses the best alternative from $W\left(x^{0}\right) \cup\left\{x^{0}\right\}$ according to $\mathrm{C}_{\mathrm{j}}(\mathrm{x}, \mathrm{y})$.

We can also show that equilibria exist under these circumstances. Let $x=C_{j}(x, y)$ $\forall y \varepsilon W\left(x^{0}\right) \cup\left\{x^{0}\right\}$. If $x=x^{0}$, then no change occurs. If $x \neq x^{0}$, then by (A2) the committee proposes $x$. Since $x \in W\left(x^{0}\right)$, then by definition $x$ is passed by majority vote, and $x=$ $C(x, y)$. To define the equilibrium state, let $S(x)$ be the set of points preferred to $x$ by the committee. That is, $S(x)=\{y \varepsilon X \mid y=C(x, y)\}$.

Definition: A structure induced equilibrium is a point

$$
\mathrm{x}^{*} \text { s.t. } \mathrm{S}\left(\mathrm{x}^{*}\right) \cap \mathrm{W}\left(\mathrm{x}^{*}\right)=\phi
$$

Under these circumstances, a generalization of Shepsle's results may be proved. ${ }^{59}$

THEOREM: If the legislators' preferences may be represented by strictly quasiconcave, continuous utility functions, and if $\mathrm{C}_{\mathrm{j}}(\mathrm{x}, \mathrm{y})$ is well-defined, then structure-induced equilibria exist for the legistative committee system. 
